\title{
The Utilization of Lobsters by Humans in the Mediterranean Basin from the Prehistoric Era to the Modern Era - An Interdisciplinary Short Review
}

\author{
By Ehud Spanier*
}

The Mediterranean and Red Seas host a variety of clawed, spiny and slipper lobsters. Lobsters' utilization in ancient times varied, ranging from complete prohibition by the Jewish religion, to that of epicurean status in the Roman world. One of the earliest known illustrations of a spiny lobster was a wall carving in Egypt depicting the Queen Hatshepsut expedition to the Red Sea in the 15th century BC. Lobsters were known by the ancient Greeks and Romans as was expressed in art forms and writings. Lobsters also appeared in ancient mosaics and coins. The writings of naturalists and philosophers from the Roman-Hellenistic period, together with illustrative records indicate that lobsters were a popular food and there was considerable knowledge of their classification, biology and fisheries. The popularity of lobsters as gourmet food increased with time followed by an expansion of the scientific knowledge as well as over exploitation of these resources.

Keywords: Antiquity, Biology, Fisheries, Lobsters, Mediterranean.

\section{Introduction}

A variety of edible lobsters, that are still commercially significant to human inhabitants today, are found in the water of the Mediterranean and adjacent Red Sea regions. This important marine resource includes at least two Mediterranean clawed lobsters (the European lobster, Homarus gammarus, and the Norway lobster, Nephrops norvegicus), five spiny lobsters (two in the Mediterranean: the common spiny lobster, Palinurus elephas, and the pink spiny lobster, $P$. mauritanicus; and three in the Red Sea: the ornate spiny lobster, Panulirus ornatus, the pronghorn spiny lobster P. penicillatus, and the painted spiny lobster, $P$. versicolor), and five species of slipper lobsters (three in the Mediterranean - the small European locust lobster, Scyllarus arctus, the pygmy locust lobster, S. pygmaeus, and the Mediterranean slipper lobster, Scyllarides latus and two in the Red Sea: the Aesop slipper lobster, Scyllarides haanii, and the clam-killer slipper lobster, S. tridacnophaga) (Holthuis 1968, 1991).

Lobsters have been extant in the world oceans for several hundred million years. The origin of the first lobster-like decapod (probably Polychelida) was

\footnotetext{
* Professor, The Leon Recanati Institute for Maritime Studies \& Department of Maritime Civilizations, The Leon H. Charney School for Marine Sciences, University of Haifa, Israel.
} 
estimated in the Devonian (approximately 409-372 million years ago). These early forms likely occupied deep water similar to their present living representatives (Bracken-Grissom et al. 2014). The ancestors of spiny and slipper lobsters appeared about 250 million years ago (Patek et al. 2006, Bracken-Grissom et al. 2014) and fossil remains of clawed lobsters are known from the early Cretaceous (about 145-105.5 million years ago) (Wahle et al. 2012). Modern human, Homo sapiens, however, is a much younger species, reaching anatomical modernity nearly 200,000, exhibiting full behavioral modernity approximately 65,000 years ago (McDougall et al. 2005, Mellars 2006), when modern groups of lobsters were already present and probably distributed much as they are today.

The Mediterranean and the nearby Red Seas are considered the cradle of creation for several coastal and maritime civilizations (Thiery 1986). Fish remains were found at Palaeolithic to Late Bronze Age sites in the eastern Mediterranean (Van Neer et al. 2005). Galili et al. (2002), presents evidence that the inhabitants of, now submerged, coastal Neolithic village of Athlit-Yam off northern Israel, used marine resources. In addition to remains of many fishes and basic fishing gear, some similar to those used today (e.g., stone net sinkers, fishing hooks, Galili et al. 2004), a relatively rare ear syndrome, auditory exostosis, caused by diving in cold water, was observed in at least 4 male skeletons recover from this site. The finding of this syndrome most probably indicates that the male population of this, 8000 years old, Neolithic settlement, fished and collected marine food through free diving (Hershkovitz and Galili 1990).

The goal of the present brief review is to address several questions regarding the utilization of lobsters by humans in the Mediterranean Basin in the past. Among them: what species of lobsters did ancient human societies fish and how did they catch them? Was their exploitation at sustainable level? Did humans preserve lobsters and trade with them? What was their relative economic/nutritious value to humans' societies? Did the ancients utilize lobsters for other functions than food? What was the symbolic/religious significant of lobsters for the ancients? How lobster fisheries developed over time?

\section{Materials and Methods}

The sources of information about the utilization of lobsters by ancient Mediterranean civilizations are archaeological data in the form of midden findings, ancient artwork (graphical sources such as depictions, wall drawings, mosaics, coins, pictures, sculptures) and rituals, oral traditions, and written records. The detection of remains of lobsters in archeological sites from historical and especially prehistoric eras presents several difficulties. Many ancient shorelines and coastal settlements are now submerged due to global rising sea levels during the last 20,000 years, (van Andel 1989, Bailey et al. 2007). Thus, data collection from them is very difficult or even impossible. 
Hard remains of shelled marine animals, such as mollusk shells and fish bones, are not rare in prehistoric and historic middens ("kitchen remains") and have been often identified and analyzed to the species level. However, those of more fragile shells, such as echinoderms and crustaceans, including lobsters, have been largely ignored in most zoo-archaeological literature (e.g., Zugasti 2011). One explanation for this is the composition of relatively thin exoskeletons (compared to the thick shells of mollusks), which leads to degradation and dissolution over time leaving behind no recognizable remains in archaeological digs. This degradation and dissolution occurs by the action of carbonic acid generated through the interaction of rainwater and $\mathrm{CO}_{2}$ and removes all but the thickest parts of the shell, leaving behind, in the case of lobsters, just small pieces of the thickest fragments such as the claw, the mandibles, and possibly gastric mill teeth. Only in middens that were in a dry site, such as caves protected from rain, would such portions manage to survive the weathering of thousands of years, and even then, it may be difficult to identify the remains as belonging to a lobster taxon instead of a crab taxon without DNA analysis. Therefore, some of the oldest lobster exoskeletal remains found in South African middens (usually in dry caves), date only hundreds to about 8,000 years in age, while remains of mandibles can date to over 11,000 years of age (Jerardino and Navarro 2002). Frequently these remains require careful sifting of soils in the midden to locate and thus may be easily overlooked. An additional problem can occur during screening, when objects are removed from the filtered material. If the screener does not recognize an element as potentially identifiable, then it may be discarded, especially when there is an abundance of other non-related small shell fragments. In contrast, fish bones can date up to 75,000 years in age in middens (Yellen et al. 1995). The taxonomic group of lobsters exploited in ancient times may also affect the durability of the remains. For example, although slipper lobsters (Scyllaridae) have thicker exoskeleton than spiny lobsters (Palinuridae) and especially clawed lobsters (Nephropidae) (e.g., Barshaw et al. 2003, Tarsitano et al. 2006), they do not have the heavily calcified mandibles seen in the palinurids, nor the heavily calcified claws of the nephropids, so evidence of their use may be difficult to assess from midden sampling alone. Consequently it is not clear if the scarcity or absence of crustacean remains in archaeological records is the result of their inaccessibility and/or avoidance by ancient peoples, the decomposition of the remains with time, or the outcome of sampling bias.

Ancient graphic illustrations of lobsters from wall drawings, mosaics, coins, pictures, and sculptures also may be problematic for determining which species were exploited due to difficulties in identifying the species of the lobster illustrated (although, as will be demonstrated later, some mosaics from classical times are so accurate that one can easily identify the lobster to the species level). Even written historical sources on lobsters are occasionally hard to interpret due to difficulties and confusion in the nomenclature. For example

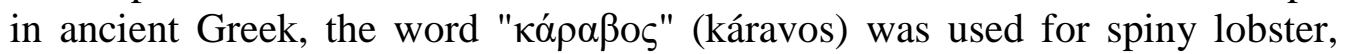

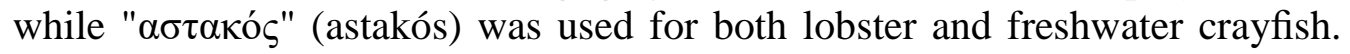


Aristotle used the term " $\alpha \sigma \tau \alpha \kappa o ́ \varsigma "$ mostly for the European clawed lobster, Homarus gammarus. Unfortunately, his use of names was not very specific, and thus it is not easy to identify the animal that corresponds to each name (Koutrakis et al. 2009). Despite these difficulties and the patchy and occasionally scarce information available on lobster utilization in certain periods and regions, this brief review attempts to discuss the deep history of human exploitation of lobster species in the Mediterranean basin and adjacent areas. It is hoped that this brief review stimulate further research on this subject by archaeologists, anthropologists, marine biologists and other scientists.

\section{Results and Discussion}

\section{The Prehistoric Era}

Records of lobster remains in the Mediterranean - Red Sea regions are extremely rare. One exception is the recent finding (2011) of the end of a claw (chela) of $H$. gammarus by Stefano Masala (supervised by Dr. Barbara Wilkens, Department of environmental sciences, University of Sassari, Italy) among other kitchen refuse (mostly marine) dated to the end of $7^{\text {th }}$ century BCE (early Iron Age) in the nuragic village of Sant'Imbenia near Alghero, in northern Sardinia, Italy (Wilkens personal communication 2014). The considerable size of the crushing teeth indicates a sizeable lobster. Considering this single finding, is it possible that very big European lobsters where not rare in the shallow water of the Mediterranean during prehistoric times?

\section{The Ancient Era}

Although archeological and historical information on exploitation of lobsters by humans in the Mediterranean-Red Sea basin is some time patchy, evidence indicates that the attitude to lobsters utilization in ancient times in this region was variable. It ranged from the complete prohibition of lobster (and other marine invertebrates/varmints) consumption by the Jewish religion (e.g., Old Testament, Leviticus 11) to that of Epicurean status in the HellenisticRoman world (see below).

The earliest depiction of lobster is apparently that on a $15^{\text {th }}$ century BCE mural on a temple wall in Deir el-Bahari, Egypt (Hayes 1973, Monod and Laubier 1996, Glenister 2008). This bas-relief commemorated the five-ship trade voyage of Queen Hatshepsut, of the Eighteenth Dynasty of ancient Egypt, to the land of Punt in the southern Red Sea. The lobster, carved together with other, mostly edible, tropical (Red Sea) marine animals (Danelius and Steinitz 1967), is a spiny lobster that some scholars (e.g., Schmitt 1931, André 1957, Hubschman 1979) suggested to be $P$. penicellatus.

However more information on lobsters in the ancient era in this region comes from Greek-Roman sources.

Although it is rare to find lobsters on coins, a notable exception comes from small bronze coins found in Priapos, in the region of Mysia in northwestern Asia Minor, from the $3^{\text {rd }}$ century BCE with a figure of a lobster 
(e.g., Gardner 1913) that seems to be P. elephas. Later visitors noted that this area was a good source of "crabs" (Konuk 2010). Even more unusual is to find lobsters on rings from these periods such as the image that appears on an archaic Greek silver finger ring from Gela, Sicily, second half of the $6^{\text {th }}$ century BCE (Spier 1992).

Lobsters were the subject of black-glazed figural askos vases, such as a terracotta vessel in the form of a lobster claw, Greece circa $400-460$ BCE (e.g., http://www.christies.com/lotfinder/ancient-art-antiquities/an-attic-blackglazed-figural-askos-class-of-5321793-details.aspx). These were complex structures made via molds and free modeling. Lobsters occasionally decorated Roman table utensils and also appeared on wall drawings and reliefs. However the bulk of the information on lobsters from the Ancient Era in the Mediterranean Basin comes from written text and mosaics (for a detailed list see Table I in Charmantier 2014).

Some mosaics include the use of lobster organs such as the illustration of Pontus ("Oceanus", an ancient, pre-Olympian sea-god) in an ancient Roman mosaic, from Neapolice, Tunisia, $3^{\text {rd }}$ century BCE (Fradier 1982) or just parts of lobsters, e.g., legs of a spiny lobster in the "Un-swept floor" (originally a mosaic from Pergamon, $3^{\text {rd }}$ century BCE) (Orange and Nordhagen 1966). There are Hellenistic-Roman mosaics that portray unspecific organisms that somehow resemble lobsters (e.g., the lobster-like figure in the $4^{\text {th }}$ century CE Thiasos Marino mosaic, Villa Romana del Casale in Piazza Armerina, Sicily (Romero 2011). Yet there are quite a few mosaics where the depicted lobsters are accurate and can easily be identified at the species level. This accuracy in biological details indicates that the artists were familiar with the animals and had observed them closely. E.g., the lobster appearing in a $3^{\text {rd }}$ century CE Roman mosaic from Thugga (Dougga, as it is called today) in the "House of Dionysus and Ulysses" (Poinssot 1965), is easily determined as P. elephas. Many mosaics where lobsters can be identified are associated with representations of fishing activities.

Despite some confusion in nomenclature, as mentioned above, the Greeks and Romans had good knowledge on biological and fisheries aspects of several species of Mediterranean lobsters. Already Hippocrates (circa 460 -370 BCE) sorted the Mediterranean lobsters to several "types" (Lloyd and Chadwick, 1984). Pliny the Elder (Gaius Plinius Secundus, $1^{\text {st }}$ century CE) (Rakham 1962), Aristotle $\left(4 \mathrm{t}^{\mathrm{h}}\right.$ century BCE) (d'Arcy-Thompson 1952) and Aelian (Claudius Aelianus, circa 175-235 CE) (Scholfield 1958) classified lobsters as "animals without blood". These ancient scholars supplied detailed information about the morphology of the lobsters. They recognized lobsters as animals with five legs on each side and provided detailed and precise descriptions of the claws (in the "astakós"), the spines and the thorny antennae (in the "káravos"), tail, eyes, colors and other external features. Classical naturalists such as Pliny the Elder, Aristotle and Oppian (Oppianus, $2^{\text {nd }}$ century CE) (Mair 1963) described the rocky cave habitat and gregarious behavior of the spiny lobsters and mentioned the clawed lobsters as "living among rocks". They also wrote about territoriality, homing, and seasonal movements of lobsters from shallow 
water in winter to deeper water in summer. They had some knowledge on reproduction and physiology of lobsters since their descriptions included courtship, "copulation", laying, incubation and release of eggs. Aristotle even described tiny "káravos" "smaller than a finger" (apparently first benthic stage). These ancient naturalists supplied reports on the phenomena, process and timing of molting in all types of lobsters known to them. The four classical naturalists mentioned above, as well as Plutarch (Lucius Mestrius Plutarchus, circa 46-120 CE) in his "Moralia -De sollertia animalium" (On the skills of animals) (Babbit 1957) mentioned the octopus as a predator of lobsters. The interactions between the common octopus (Octopus vulgaris), as a predator of several "types" of Mediterranean lobsters, and the Mediterranean moray eel (Muraena helena) not only was described in details by all the above mentioned ancient naturalists but also appears in several ancient Roman mosaics. This is the case with the famous and most beautiful mosaic from Pompeii (house n. 16, insula 2, Regio VIII; $1^{\text {st }}$ century CE) (Ward-Perkins and Claridge 1978) describing $O$. vulgaris attacking $P$. elephas while the first organism is threatened by $M$. helena. Modern lobster scientists observing Mediterranean lobsters sharing dens with moray eels, with no apparent predator-prey interactions between the fish and the lobsters could not explain this cohabitation until they observed the above mentioned ancient mosaic. AlmogShtayer et al. (1989) suggested that since lobsters were also the prey of octopuses and the later were preyed by morays, shelter sharing of the decapods and the fish could have mutual benefits. The lobster may be protected by the moray, which preys on octopuses, and the moray eel may take advantage of any octopus attracted to the shared den by the presence of its prey - the lobster. Aristotle, Pliny, and Aelian supplied also detailed and correct accounts of the backward escape swimming (tail-flip) of lobsters when in danger, an effective anti-predator adaptation known to date in several species of lobsters (e.g., Spanier et al. 1991).

The Roman and Greek fishermen knew the proper habitats, seasons and methods to catch various kinds of lobsters. Aristotle pointed to these preferred fishing habitats and also mentioned the use of baits to catch lobsters. The Greek poet Theocritus ( $4^{\text {th }}$ century BCE) in his work "The idylls" (Holden 1974), remarked lobsters as superb food that can be caught with lobster pots (traps) made of weaved reed. This type of lobsters pots can be seen in several Roman mosaics describing fishing scenery (fishermen in a boat, $2^{\text {nd }}$ century CE from the "Catacombs of Hermes", Hadrumetum (Sousse), Tunisia (Fradier 1982)). Similar weaver baskets lobster traps were photographed by the author in Sardinia in 2010 and are known also from Africa, Brazil and elsewhere (e.g., McChesney et al. 1991).

Lobsters topics appear also in metaphors in classical comedies, tragedies and poems of ancient Greek and Roman writers. They were described as an excellent food also by Epicharmus (circa 540-450 BCE) (Rodríguez-Noriega Guillén 1996) and Aristophanes (circa 446 -386 BCE) ( Henderson 2000), and in cooking books, one of oldest of which, the Deipnosophistae ("dinner- table philosophers"), was written by Athenaeus $\left(2^{\text {nd }}-3^{\text {rd }}\right.$ century CE) (Gulick 1957) 
as well as in De re culinaria, a collection of Roman cookery recipes attributed to Apicius, but apparently compiled a lot later (circa $4^{\text {th }}-5^{\text {th }}$ century CE), that included several lobster recipes (Vehling 1977). These records indicate that lobsters were popular food for ancient Romans and Greeks, who fished them intensively and often paid a steep price for them; ancient Romans even transported lobsters and other shellfish inland over considerable distances (Townsend 2011). The role of lobsters as a prestigious food in ancient Mediterranean societies is demonstrated by Marcus Gavius Apicius. This Roman gourmet chef $\left(1^{\text {st }}\right.$ century $\left.\mathrm{CE}\right)$, was reportedly so fond of slipper lobsters that, once he heard about their size and excellence on the coast of Tunisia, he sent a special expedition to collect them for himself and his guests (Dalby 2003, Grocock and Grainger 2006). He was also the supposed author of several lobster recipes. Lobsters were a gourmet food for the wealthy in the Hellenistic-Roman world and were featured in feasts (Dalby 2003). Pliny the Elder wrote about a "Leviathan spiny lobster" about 1.8-2.4 $\mathrm{m}$ in length! (King 2011). Was this Pliny's imagination or were lobsters indeed that large in the Ancient Era? The Roman emperor Maximinus (Gaius Julius Verus Maximinus Augustus, $3^{\text {rd }}$ century CE), the first barbarian to hold the title and a man of colossal size ("2.5 m in height") was reported to have eaten 20 lobsters at one seating (King 2011). Some sources claimed that a supper of stewed lobsters had inspired one of Cicero's greatest speeches (e.g., King 2011). The therapeutic properties of lobsters were recorded and had a prominent role in the medical practice during the ancient Greek, Roman and the early Byzantine periods (King 2011). Lobsters parts were used, among other remedies, as laxative, kidney stone treatment, strengthener of the body's immune system and as a treatment for poisoning (Voultsiadou 2010). During ancient Greece and Rome, as well as in the Middle Ages, lobsters were highly appreciated aphrodisiacs (Melnyk and Marcone 2011, Pajovic et al. 2012, and references therein).

\section{The Middle Ages and Renaissance}

Limited information was found on the use of lobsters by Mediterranean people from the Byzantine period, mainly because a decline of non-religious art during this time period. However, one mosaic from a Byzantine church from circa $6^{\text {th }}$ century CE from Bet Guvrin, southern Israel (Ovadiah and Ovadiah 1987) is of special interest. This mosaic includes two figures of clawed lobsters that seem to be $H$. gammarus which is peculiar because Israel is out of the present distribution range of this species (Holthuis 1991) or any other species of clawed lobsters. Almog-Shtayer (1988) suggested several possible explanations: either that the artist who created the mosaic was from the western part of the Byzantine Empire where H. gammarus was common, or the artist used a models' book that originated from the western region, a practice that was common in ancient Mediterranean cultures. Another hypothetical assumption that Almog-Shtayer postulated was that during the Little Ice Age (ranging in time from 2000 to 500 years ago) H. gammarus may have extended into the southeastern Mediterranean. 
In the Middle Ages, mosaic representations of common activities were replaced by paintings. Many members of the high society employed their own exclusive painters. Still life or quotidian scenes often depicted the types of food and, in some cases, species consumed. Although lobsters at this time also had importance and were accurately depicted in numerous works of art (e.g., Charmantier 2014), there is generally a lack of information for this period. It is likely that spiny lobsters were continuously fished and consumed by the local coastal villages. Despite the very limited evidence available on lobster utilization in the medieval period, it seems that lobsters continued to be esteemed food in the Mediterranean.

\section{The Modern Era}

The reputation of lobsters as excellent food in the Mediterranean continued in the late Renaissance and the early modern era as expressed in many paintings depicting Mediterranean lobsters such as H. gammarus and Scyllarus sp. (see Table I in Charmantier 2014) and literature (e.g., Crane 2009). Decrease in the fishery yields of several Mediterranean lobsters' species in some heavily fished areas has started well before the $20^{\text {th }}$ century and deterioration of the stocks has worsen in the last two centuries with the intensification of the efforts and introduction of modern technologies. Yet, regulations of lobsters' fisheries in the Mediterranean have started, partially, only in the late modern time. Landings for P. elephas In the Mediterranean basin peaked in the 1960's and then declined even with increased effort, although it is believed that many landings of this species go unreported (Groeneveld et al. 2013). The European Union set a minimum landing size for $P$. elephas, but otherwise all other management efforts are the responsibility of the affected countries or are done via regional agreements. Thus, some management schemes involve an annual seasonal closure that varies regionally in duration, prohibitions against taking ovigerous females, and establishing of a few marine protected areas where no fishing is allowed (Groeneveld et al. 2013). Despite these regulations, at-sea enforcement is difficult especially since there are a large number of fishing vessels in the Mediterranean. Many regions in this basin have no regulation and /or enforcement at all. The outcome of the lack of management regulations of lobsters' fisheries or their implementation, despite increasing demand and fishing efforts, are sever reduction of lobster populations in many parts of the Mediterranean and even extreme overfishing (e.g., N. norvegicus, Sarda et al. 1998, P. elephas, Groeneveld et al. 2013, S. latus, Spanier and Lavalli 2013). In recent years, landings of $H$. gammarus from some regions in the Mediterranean countries have fallen to zero (Wahle et al. 2013) and these hold also for other species of lobsters in many Mediterranean fishing grounds. 


\section{Acknowledgments}

The trigger for the present paper was a special session and a keynote address on the history of utilization of lobsters by humans around the world during the $10^{\text {th }}$ International Conference and Workshop on Lobster biology and management $\left(10^{\text {th }}\right.$ ICWL), Cancun, Mexico, 18-23 May, 2014. A concise review on lobster utilization by worldwide human populations from pre-history to the modern era is now in advance preparation for publication in ICES Journal of Marine Science. Thanks are due to the participants of this special session and especially to Dr. Kari L. Lavalli, Boston University, USA, Dr. Jason S. Goldstein, University of New Hampshire, USA, Marco L. Bianchini, IAMC-CNR, Italian National Research Council, Italy and to Rebecca D. Kibler, USA.

\section{References}

Almog-Shtayer G (1988) Behavioral-ecological aspects of Mediterranean lobsters in the past and of the slipper lobster, Scyllarides latus, in the present. Master Thesis, University of Haifa, Israel. (in Hebrew with English abstract): 165.

Almog-Shtayer G, Spanier E, Artzy M (1989) What can we learn about the behavioral ecology of Mediterranean lobsters from ancient sources. In E Spanier, M Luria and Y Steinberger (Eds), Ecosystems Stability and Environmental Quality, IV. Jerusalem: ISEEQS: 371-379.

André M (1957) Crustacés dans les legends anciennes et actuelles [Crustaceans in the past and present legends]. L'Ethnographie 52: 107-131.

Babbit FC (1957) Plutarch's Moralia. London: William Heinemann.

Bailey GN, Flemming NC, King GCP, Lambeck K, Momber G, Moran LJ, AlSharekh A, Vita-Finzi C (2007) Coastlines, submerged landscapes and human evolution: the Red Sea Basin and the Farasan Islands. Journal of Island and Coastal Archaeology 2: 127-160.

Barshaw D E, Lavalli KL and Spanier E (2003) Offense versus defense: responses of three different morphological types of lobsters to predation. Marine Ecology Progress Series 256: 171-182.

Bracken-Grissom HD, Ahyong ST, Wilkinson RD, Feldmann RM, Schweitzer CE, Breinholt JW, Bendall M, Palero F, Chan T-Y, Felder DL, Robles R, Chu KH, Tsang LM, Kim D, Martin JW, Crandall KA (2014) The emergences of the lobsters: phylogenetic relationships, morphological evolution and divergence time comparisons of an ancient group (Decapoda: Achelata, Astacidea, Glypheidea, Polychelidae). Systematic Biology 63(4): 457-479.

Charmantier G (2014) Crustaceans in art. Chapter 27B. In The Crustacea, Traite de Zoologie 4A, Ed JC von Vaupel Klein, M Charmantier-Daures, FR Schram. Boston: Koninklijke Brill, Leiden: 139-187.

Crane MT (2009) Illicit privacy and outdoor spaces in early modern England. Journal for Early Modern Cultural Studies 9(1): 4-22.

Dalby A (2003) Food in the ancient world from A to Z. London: Routledge.

Danelius E, Steinitz H (1967) The fishes and other aquatic animals on the Punt-reliefs at Deir el-Bahri. Journal of Egyptian Archaeology 53: 15-24. 
d'Arcy-Thompson W (1952) The works of Aristotle Vol 4. Historia animalium. Oxford: Clarendon Press.

Fradier G (1982) Mosaiquees Romaines de Tunisie [Roman Mosaics of Tunisia]. Tunis: Editions Ceres Productions.

Galili E, Rosen B, Gopher A, Horwitz LK (2002) The emergence and dispersion of the Eastern Mediterranean fishing village: evidence from submerged neolithic settlements off the Carmel Coast, Israel. Journal of Mediterranean Archaeology 15(2): 167-198.

Galili E, Lernau O, Zohar I (2004) Fishing and coastal daptations at Atlit-Yam-a submerged PPNC village off the Carmel coast, Israel. Atiqot 48: 1-34.

Gardner P (1913) Coinage of the Athenian empire. The Journal of Hellenic Studies 33: $147-188$

Glenister CL (2008) Profiling Punt: using trade relations to locate "God's Land". Master Thesis. University of Stellenbosch, South Africa.

Grocock C, Grainger S (2006) Apicius: a critical edition with an introduction and an English translation. Devon: Prospect Books, Allaleigh House, Blackawton, Totnes.

Groeneveld JC, Goñi R, Diaz D (2013) Palinurus Species. In B F Phillips (Ed) Lobsters: biology, management, aquaculture and fisheries, 2nd edition. Oxford, UK: Blackwell Scientific Publications: 326-356.

Gulick CB (1957) Athenaeus: "The Deipnosophists" LCL, Vol. 1. The Loeb Classical Library. London: William Heinemann.

Hayes WC (1973) Egypt: internal affairs from Tuthmosis I to the death of Amenophis III. In IES Edwards, CJ Gadd, NGL Hammond, S Sollberger (Ed) The Cambridge Ancient History, II. Cambridge: Cambridge University Press: 313416.

Henderson J (2000) Aristophanes: "Birds"; "Lysistrata"; "Women at the Thesmophoria". Cambridge, MA: Harvard University Press.

Hershkovitz I, Galili E (1990) 8000-Year-Old Human Remains on the Sea Floor near Atlit, Israel. Human Evolution 5: 319-58.

Holden A (1974) Theocritus: "The idylls". UK: Harmondsworth, Penguin.

Holthuis LB (1968) The Palinuridae and Scyllaridae of the Red Sea. Zoologische Mededelingen 42: 281-301.

Holthuis LB (1991) FAO Species Catalogue 13(125). Marine Lobsters of the World. Rome: Food and Agricultural Organisation.

Hubschman JH (1979) The lowly invertebrates: a historical perspective. Ohio Journal of Science 79(6): 243-248.

Jerardino A, Navarro R (2002) Cape rock lobster (Jasus lalandii) remains from South African west coast shell middens: preservational factors and possible bias. Journal of Archaeological Science 29: 993-999.

King RJ (2011) Lobster. London: Reaction Books.

Konuk K (2010) The payment of the ekklesiastikon at Iasos in the light of new evidence. Hellenistic Karia 12: 59-6.

Koutrakis E, Machino Y, Mylona D, Perdikaris C (2009) Crayfish terminology in ancient Greek, Latin, and other European languages. Crustaceana 82(12): 15351546.

Lloyd GER, Chadwick J (1984) Hippocrates writings. London: Penguin Classics. 
Mair AW (1963) Halieutica by Oppian, Coluthus, Tryphiodorus. London: William Heinemann.

McChesney JD, Clark AM, Silveira ER (1991) Antimicrobial diterpenes of Croton sonderianus. 1. Hardwickic and 3, 4-secotrachylobanoic acids. Journal of Natural Products 54: 1625-1633.

McDougall I, Brown FH, Fleagle JG (2005) Stratigraphic placement and age of modern humans from Kibish, Ethiopia. Nature 433: 733-736.

Mellars P (2006) Why did modern human populations disperse from Africa ca. 60,000 years ago? A new model. Proceedings of the National Academy of Sciences 103(25): 9318-9386.

Melnyk JP, Marcone MF (2011) Aphrodisiacs from plant and animal sourceses, a review of current scientific literature. Food Research International 44(4): 840850.

Monod T, Laubier L (1996) Les Crustacés dans la biosphère [Crustaceans in the biosphere]. In J Forest (Ed) Traité de zoologie: anatomie, systématique, biologie: VII. Crustacés: 2. Généralités (suite) et systématique. Paris: Masson : 91-166.

Old Testament Leviticus 11: 10-12.

Orange HPL, Nordhagen PJ (1966) Mosaics: from Antiquity to the early Middle Ages. London: Methuen.

Ovadiah R, Ovadiah A (1987) Hellenistic, Roman and early Byzantine mosaic pavements in Israel. "L'erma di Bretschneider". Rome.

Pajovic B, Radosavljevic M, Radunovic M, Rdojevic N, Bjelogrlic B (2012) Arthropods and their products as aphrodisiacs - review of literature. European Review for Medical and Pharmacological Sciences 16: 539-547.

Patek SN, Feldmann RM, Porter M, Tshudy D (2006) Phylogeny and evolution of lobsters. In BF Phillips (Ed) Lobsters: Biology, Management, Aquaculture and Fisheries. Oxford: Blackwell Publishing: 113-145.

Poinssot C (1965) Quelques remarques sur les mosaïques de la Maison de Dionysos et d'Ulysse à Thugga (Tunisie) [Some remarks on the mosaics in the House of Dionysus and Ulysses Thugga (Tunisia)]. In La mosaïque gréco-romaine. Paris 29/08-03/09/1963: 219-232.

Rakham H (1962) (Translator). Pliny the Elder: Natural History 3. The Loeb Classical Library. London: William Heinemann.

Rodríguez-Noriega Guillén L (1996) Epicarmo de Siracusa: testimonios y fragmentos. Edición crítica bilingüe [Epicarmo Syracuse: testimonies and fragments. Bilingual critical edition]. Oviedo: Universidad de Oviedo, Servicio de Publicaciones.

Romero IM (2011) Mosaico romanos de Italica [Roman mosaic of Italy]. Spain: CSIC Press.

Sardà F, Lleonart J, Cartes JE (1998) An analysis of the population dynamics of Nephrops norvegicus (L.) in the Mediterranean Sea. Scientia Marina 62: 135143.

Schmitt WL (1931) Crustaceans: shelled invertebrates of the past and present. Part II. Smithsonian Scientific Series 10: 85-248.

Scholfield AF (1958) Aelian: On the Characteristics of Animals 2. Cambridge, MA: Harvard University Press.

Spanier E, Weihs D, Almog-Shtayer G (1991) Swimming of the Mediterranean slipper lobster. Journal of Experimental Marine Biology and Ecology 145: 15-31.

Spanier E, Lavalli KL (2013) Commercial Scyllarids. In BF Phillips (Ed) Lobsters: biology, management, aquaculture and fisheries, 2nd edition. Oxford: Blackwell Scientific Publications: 414-467. 
Spier J (1992) Ancient gems and finger rings catalogues. The J Paul Getty Museum, Los Angeles: Getty Publications.

Tarsitano S, FLavalli KL, Horne F, Spanier E (2006) The constructional properties of the exoskeleton of Homarid, Palinurid, and Scyllarid Lobsters. Hydrobiologia 557: 9-20.

Thiery C (1986) Past and present international cooperation on marine research in the Mediterranean. In RL Grundy, RT Ford (Ed) Marine Science Information: An International Commodity. Texas: University of Texas, Port Aransas: 155-167

Townsend E (2011) Lobster: a Global History. Chicago: Reaktion Books/University of Chicago Press: 144.

Van Andel T (1989) Late Quaternary sea-level changes and archaeology. Antiquity 63 (241): 733-745.

Van Neer W, Zohar I, Lernau O (2005) The Emergence of Fishing Communities in the Eastern Mediterranean region: A Survey of Evidence from Pre-and Protohistoric Periods. Paléorient 31(1): 131-157.

Vehlin JD (1977) Ed Apicius' Cookery and Dining in Imperial Rome. New York: Dover.

Voultsiadou E (2010) Therapeutic properties and uses of marine invertebrates in the ancient Greek world and early Byzantium. Journal of Ethnopharmacology 130: 237-247.

Wahle RA, Tshudy D, Cobb JS, Factor J, Jaini M (2012) Infraorder Astacidea Latreille, 1802 P.P.: The marine clawed lobsters. In FR Schram, JC von Vaupel Klein (Ed) The Crustacea: Traite de Zoologie 9B. Leiden: Koninklijke Brill : 3108.

Wahle RA, Castro KM, Tully O, Cobb JS (2013) Homarus. In BF Phillips (Ed) Lobsters: Biology, Management, Aquaculture and Fisheries, 2nd Edition. John Wiley \& Sons, Ltd: 221-258.

Ward-Perkins J, Claridge A (1978) Pompeii A.D. 79: Essay and Catalogue. New York: Knopf.

Yellen JE, Brooks AS, Cornelissen E, Mehlman MJ, Stewart K (1995) A middle Stone Age worked bone industry from Katanda, Upper Semliki Valley, Zaire. Science 268: 553-556.

Zugasti FIG (2011) The Use of echinoids and crustaceans as food during the Pleistocene-Holocene transition in Northern Spain: methodological contribution and dietary assessment. Journal of Island \& Coastal Archaeology 6: 115-133. 